\title{
The Impression of ICT in Medical Education throughout COVID-19 Pandemic: A Survey among Medical Graduates of Bangladesh
}

\author{
Md. Monirul Islam ${ }^{1}$, Jannatul Ferdoush ${ }^{2}$, S.M. Humayun Kabir Tutul ${ }^{3}$
}

\begin{abstract}
In COVID-19 pandemic, the importance of ICT in Medical education is amplified. The purpose of the study was to assess and estimate the role and impact of ICT in relation to learning on medical education and changing behavior of the students in the period of pandemic. A questionnaire survey approach was applied amid of the Bangladeshi medical undergraduates during the period of August, 2020 to November, 2020. A Google linked structured questionnaire was used and distributed to the study population via email, messenger and WhatsApp. The questionnaire was completed by 201 medical students, with $65 \%$ were female and $35 \%$ were male students. Almost all respondents $(98 \%)$ owned an android smartphone and used it to access the internet. Two-thirds (69\%) of respondents have medical and health related apps in their device, with Medscape being the most widely utilized app. Respondents (49\%) encountered bandwidth trouble during online class. For collaborative learning with classmates, $76 \%$ respondents favored messenger and whatsApp group. ICT knowledge should be included in the curriculum, according to 57\% respondents. Over one-third participants, $37.3 \%$, were neither satisfied nor dissatisfied. $30.8 \%$ respondents were satisfied while $19.4 \%$ were dissatisfied. The long-term benefits and problems of reforming the medical education system and utilizing ICT technologies should be considered. In this pandemic circumstance, digitalization of learning can give essential foundations for future medical education, aided by ICT tools. Our study may be used as a foundation for future research into developing digital teaching models in medical education.
\end{abstract}

Keywords: ICT, Social Media, Medical Education, Pandemic, Bangladesh

1. Librarian, Army Medical College Chattogram, Chattogram Cantonment

2. Associate Professor, Army Medical College Chattogram, Chattogram Cantonment

3. Assistant Librarian, National Health Library \& Documentation Centre (NHL\&DC), Dhaka

Address of correspondence: Md. Monirul Islam, Librarian, Army Medical College Chattogram, Chattogram Cantonment, email: mislamdu@gmail.com

\section{Introduction:}

The covid-19 pandemic has shifted medical students' away from clinical settings and transferred medical education toward online learning (kachra and Brown, 2020). Medical faculty members are utilizing a variety of digital infrastructure technologies to maintain the continuation of medical education in the context of the pandemic. The application of ICT has achieved

eminence

in

education, markedly for medical science education globally ${ }^{1}$.

As integral part of modern life, most of the people of the country involved with education system. So any development will be incomplete without the development of this system. The development of a country is absolutely depending on the progress of educational sector ${ }^{2}$. The internet may be the

Bangladesh Journal of Medical Education 2022; 13(1); Islam et al., publisher and licensee Association for Medical Education. This is an Open Access article which permits unrestricted non-commercial use, provided the original work is properly cited. 
unparalleled resources of information and health science students cannot be constant detached from it. The progress to comprise IT into initial stage of medial syllabus was instigated in excess of few years back; adversely awfully little progression had been shaped towards achieving the target. Medical students applied the electronic devices for their necessary tasks, which cannot donate to the episode of information attainment capabilities $^{3}$. Inadequate familiarity with ICT in the context of learning did not integrate the technology into their learning process. Electronic device-based education for medical Undergraduates in supervision of different disease is reported. ${ }^{4}$.

The scientific study have revealed that the usage of digital devices in learning procedure improves the problem solving abilities $^{5}$ of medical Undergraduates. Involvement of medical Undergraduates regarding learning purpose intensely impacted through instructors. One of the major considering fact in medical learning sector at the present time is that intellectual contact a non existing tongue from the pre-distance learning era ${ }^{6}$. The depth knowledge in modern equipment increases the score of Undergraduates at exams ${ }^{7}$. Due to advancement of medicinal teaching and health learning facilities in general it is imperative to keep on close with the update information globally. Massive data we receive within a short time from online. What is noteworthy isn't minimally crucial data on the best way to devour ICT so far in adding up mechanized skill, which amalgamates the aptitude to regulate the original difficulties and circumstances in the shifting globe. This encompasses the capacities for fundamental issues recuperation, data management and the ability to make use of the upright diversity of electronic world. Hence, progression with android mobile set or smartphone and online entree along with the growing exploitation of social networking and complimentary virtual classes and reading equipment are changing the behaviors of learners in which students study, express and enroll jointly. An android set assist as a media of anyplace and any possessions and promote medical learning and health care behaviors. Escalating the stage of android set proprietorship and different medicinal apps eradicate obstacles of assuming modern equipment through rapid admittance of medical data guides to develop choice building and reduce health associated miscalculations ${ }^{8}{ }_{-}$.

Health experts keep medical books, drug procedures, syndrome strategy on their smartphone phone at present days (10) which bring update frequently. On the other hand, the service of the online or android set can't be familiarized portray common ending concerning Undergraduates' IT skill and willingness ${ }^{11}$.

The COVID-19 pandemic highlights both the flaws in the current system and the possibility to rethink educational paradigms, particularly in the context of medical education and, in the long term, the integration of ICT technologies. In the Bangladesh Journal of Medical Education 2022; 13(1); Islam et al., publisher and licensee Association for Medical Education. This is an Open Access article which permits unrestricted non-commercial use, provided the original work is properly cited. 
midst of the current crisis, ICT technologies have satisfactorily maintained educational continuity. To identify the problems of learners relating to ICT, we carried out an assessment to find out the students' evaluation concerning ICT tools and techniques in sharing academic documents, using of social media for academic purpose, performing assignment or examination during the period of Covid-19 pandemic.

\section{Materials and Methods:}

\section{Study Design and Population:}

A questionnaire method was applied on the medical undergraduate during the time of August, 2020 to November, 2020. The students were informed about their participations were voluntary and to maintain the confidentiality the response were anonymous.

\section{Study Procedure:}

A Google linked structured questionnaire was used and distributed to the study population via email, messenger and whatsapp. The questionnaire was assembled to investigate the ownership of electronic apparatus, familiarity with health related apps, and consumption the contemporary technical tools in favor of learning and experimental growth and necessity of fellows which favored proper technology guidance curriculum. A set of opinion poll was experienced within a miniature crowd of undergraduates for critic indulgent of denotation of the queries. Then survey questions were scattered headed for respondents through email, messenger and whatsapp media.
A structured questionnaire was used for data collection. Total 05 Likert scale (fivepoint) questions were developed and questionnaire was validated before survey. Data was compiled, presented and analyzed using SPSS version 25, and was expressed as percentage and mean values.

\section{Outcome measures:}

1. To find out and assess the current ICT status in medical education.

2. To find out the main problems and assess the satisfaction level of medical students on online class during pandemic situation.

\section{Result}

A total of 201 medical Undergraduates responded the feedback form. Table I represents that the female to male divisions were $64.7 \%(n=130)$ and $35.3 \%(n=71)$ correspondingly as well as shows the types of tools and use of the equipment for online class. Almost all respondents (98\%) owned an android smartphone and used it to access the internet. that $98 \%$ medical students possessed a Smartphone. Majority of the students $(84 \%)$ got access into the online class with the smartphone. $10 \%$ respondents used laptop, 4\% used desktop computer, $2.0 \%$ used tab.

Bangladesh Journal of Medical Education 2022; 13(1); Islam et al., publisher and licensee Association for Medical Education. This is an Open Access article which permits unrestricted non-commercial use, provided the original work is properly cited. 


\begin{tabular}{|l|r|r|}
\hline Table I : The respondents and the type of phone used by them $(N=201)$ \\
\hline Gender & Frequency & \multicolumn{1}{|c|}{ Percent } \\
\hline Female & 130 & $64.7 \%$ \\
\hline Male & 71 & $35.3 \%$ \\
\hline Total & 201 & $100.0 \%$ \\
\hline Types of phone they use & \multicolumn{3}{|}{} \\
\hline Featured phone (not smart phone) & 4 & $2.0 \%$ \\
\hline Smart phone & 197 & $98.0 \%$ \\
\hline Device used to access online class & 20 & $10.0 \%$ \\
\hline Laptop & 8 & $4.0 \%$ \\
\hline Desktop computer & 169 & $84.0 \%$ \\
\hline Smart phone & 4 & $2.0 \%$ \\
\hline Tablet & \multicolumn{3}{|}{} \\
\hline
\end{tabular}

\section{Sharing the academic documents}

For sharing the academic documents with fellow student, $76.0 \%$ student favored WhatsApp and Facebook messenger group.
Google drive are used by $12 \%$ student, mail used by $10.90 \%$ and $0.50 \%$ used Microsoft OneNote sharing platform during COVID19 (Figure 1).

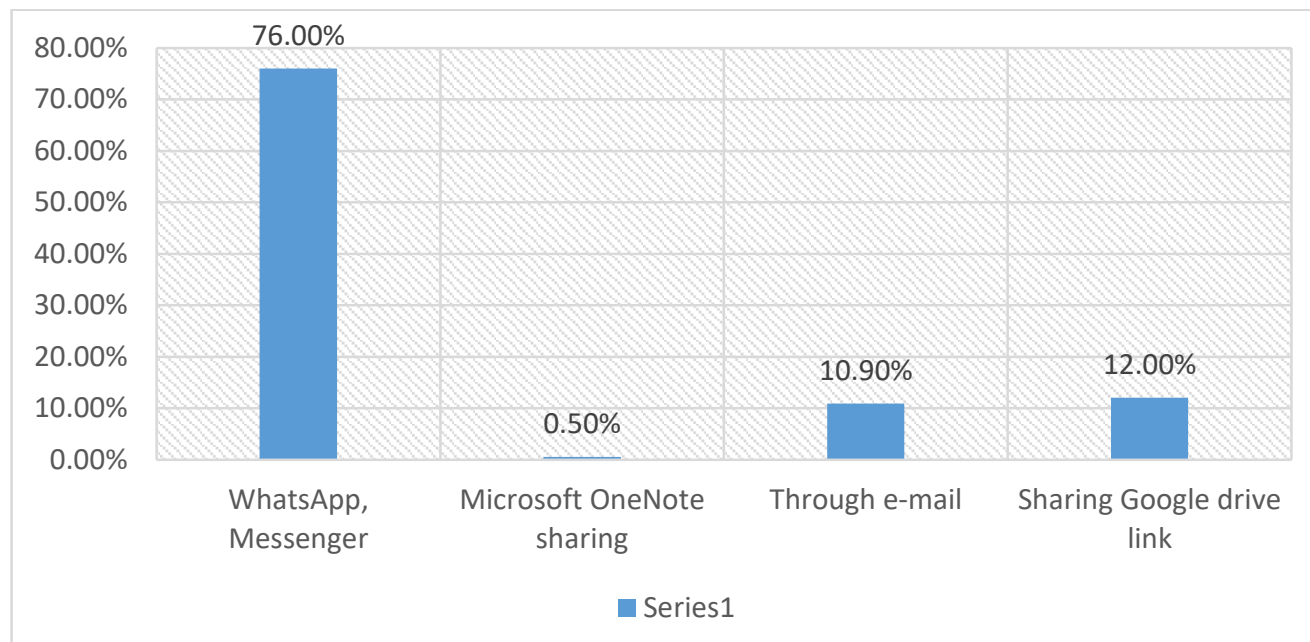

Figure 1. Use of media in collaborating academic documents in pandemic

\section{Use of Medical Apps}

The table II illustrated that the two-thirds $(68.6 \%)$ of respondents have health and drug formulary apps in their smart phone.
(39.8\%) respondents use Medscape, the $2^{\text {nd }}$ highest portion, $17.3 \%$, use PDM, followed by $14.4 \%$ use MedShr.

Among them the highest proportion

Bangladesh Journal of Medical Education 2022; 13(1); Islam et al., publisher and licensee Association for Medical Education. This is an Open Access article which permits unrestricted non-commercial use, provided the original work is properly cited. 


\begin{tabular}{|l|r|r|}
\hline \multicolumn{3}{|l|}{ Table II: Medical apps used most in mobile phone $(\boldsymbol{n}=\mathbf{2 0 1})$} \\
\hline & Frequency & \multicolumn{1}{c|}{ Percent } \\
\hline Yes & 138 & $68.6 \%$ \\
\hline No & 63 & $31.4 \%$ \\
\hline Total & 201 & 100.0 \\
\hline Apps $(n=138)$ & \multicolumn{2}{|c|}{} \\
\hline DIMS & 11 & $7.9 \%$ \\
\hline Human Dx & 8 & $5.7 \%$ \\
\hline Medscape & 55 & $39.8 \%$ \\
\hline MedShr & 20 & $14.4 \%$ \\
\hline Patient Aid & 10 & $7.2 \%$ \\
\hline PDM & 24 & $17.3 \%$ \\
\hline Prognosis & 6 & $4.3 \%$ \\
\hline Radiology 2.0 & 4 & $2.8 \%$ \\
\hline Total & 138 & 100.0 \\
\hline
\end{tabular}

Use of social media for academic purpose

For academic purpose, a combination of social media platforms is used by the medical students. The table III delineates that the highest proportion of respondents, $55.4 \%$, preferred whatsapp group, the $2^{\text {nd }}$ highest group $(20.8 \%)$ favored the messenger group, $14.4 \%$ preferred Messenger and whatsapp group both, 5.9\% liked Viber group and the small number of students $(3.5 \%)$ favored Telegram as the media of communication and exchanging with associate fellows.

\begin{tabular}{|l|r|r|}
\hline Table III. Use of social media group for academic purpose (n=201) \\
\hline & Frequency & Percent (\%) \\
\hline Messenger group & 42 & $20.8 \%$ \\
\hline Whatsapp group & 111 & $55.4 \%$ \\
\hline Viber group & 12 & $5.9 \%$ \\
\hline Telegram & 7 & $3.5 \%$ \\
\hline Messenger group, Whats app group & 29 & $14.4 \%$ \\
\hline
\end{tabular}

\section{Performing Assignment or Examination:}

The respondents were asked to provide the information regarding the media used by them to perform the assignment or exam during pandemic situation. The majority of the participants $(64.7 \%)$ stated Zoom app was the main media device to execute the task. $13.0 \%$ respondents performed through Google meet, $7.5 \%$ through Google quizzes form, $7.0 \%$ through quizzes form, messenger and whatsapp, 3.0\% through email, another $4.0 \%$ through quizzes form, whatsapp and Viber. The lowest proportion $1.0 \%$ completed task through messenger and whatsapp group both (Figure 2).

Bangladesh Journal of Medical Education 2022; 13(1); Islam et al., publisher and licensee Association for Medical Education. This is an Open Access article which permits unrestricted non-commercial use, provided the original work is properly cited. 


\section{Media to accomplish the task $(n=201)$}

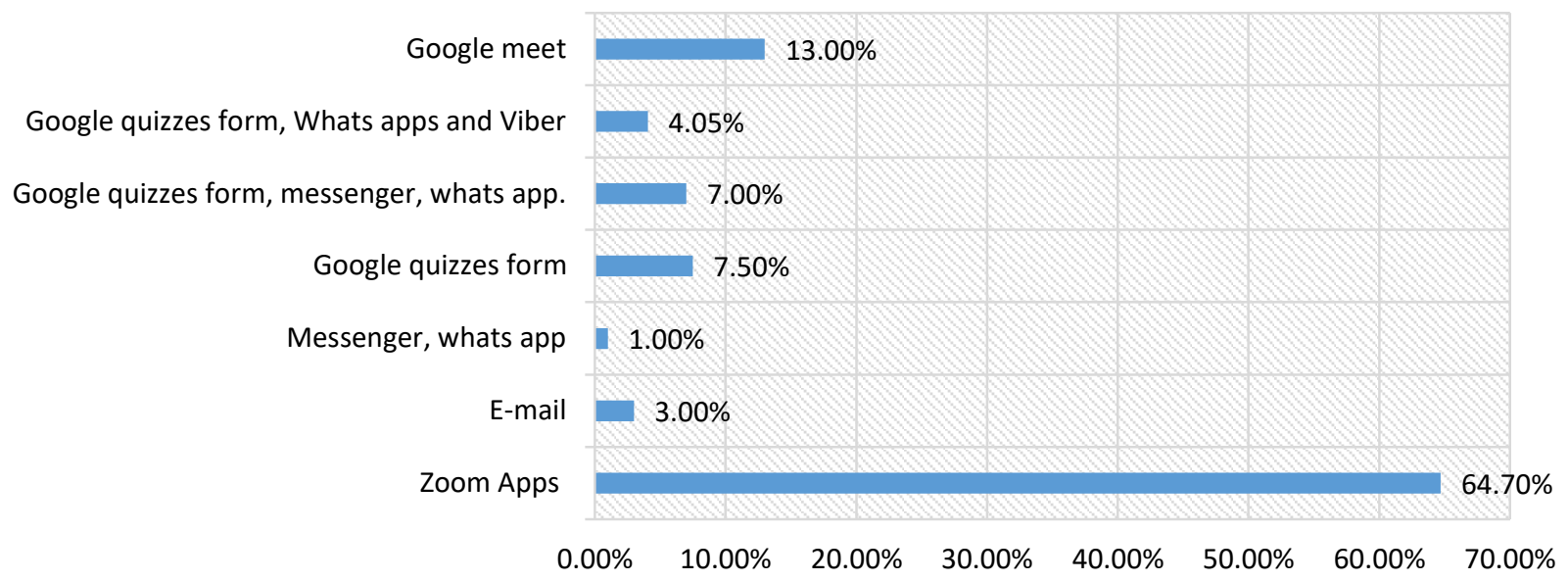

Figure 2. The media used most to complete assignment/exam

\section{Difficulties faced by the respondents}

Respondents (40.8\%) encountered bandwidth trouble during online class. Followed by $30.3 \%$ respondents found no problem, $8.9 \%$ found lack of IT knowledge, $6.5 \%$ found the problem of disconnecting in the midway, $3.5 \%$ found less qualitative presentation, $3.0 \%$ interrupted in screen sharing, $3.0 \%$ found noisy environment, $2.0 \%$ respondents found sound breaking problem another $2.0 \%$ respondents stated that their apps doesn't run properly in the period of class time (Table IV).

\section{Table IV: Problem faced by respondents}

\begin{tabular}{|l|r|r|}
\hline \multicolumn{1}{|c|}{ Problems } & Frequency & \multicolumn{1}{c|}{ Percent } \\
\hline App doesn't run in device properly & 4 & $2.0 \%$ \\
\hline Less quality presentation & 7 & $3.5 \%$ \\
\hline Disconnecting in midway & 13 & $6.5 \%$ \\
\hline Found no problem & 61 & $30.3 \%$ \\
\hline Interruption in screen sharing & 6 & $3.0 \%$ \\
\hline Lack of IT knowledge & 18 & $8.9 \%$ \\
\hline Noisy environment & 6 & $3.0 \%$ \\
\hline Sound breaking & 4 & $2.0 \%$ \\
\hline Weak Network/Bandwidth problem & 82 & $40.8 \%$ \\
\hline
\end{tabular}

\section{Satisfaction Level towards online class}

The Figure-3 illustrates the satisfaction level of the respondents towards online class held during pandemic situation. The figure shows that the highest proportion
(37.3\%) expressed that they are neither satisfied nor dissatisfied. (30.8\%) respondents were satisfied while $19.4 \%$ were dissatisfied and $9.0 \%$ were very dissatisfied where $3.5 \%$ were very satisfied.

Bangladesh Journal of Medical Education 2022; 13(1); Islam et al., publisher and licensee Association for Medical Education. This is an Open Access article which permits unrestricted non-commercial use, provided the original work is properly cited. 


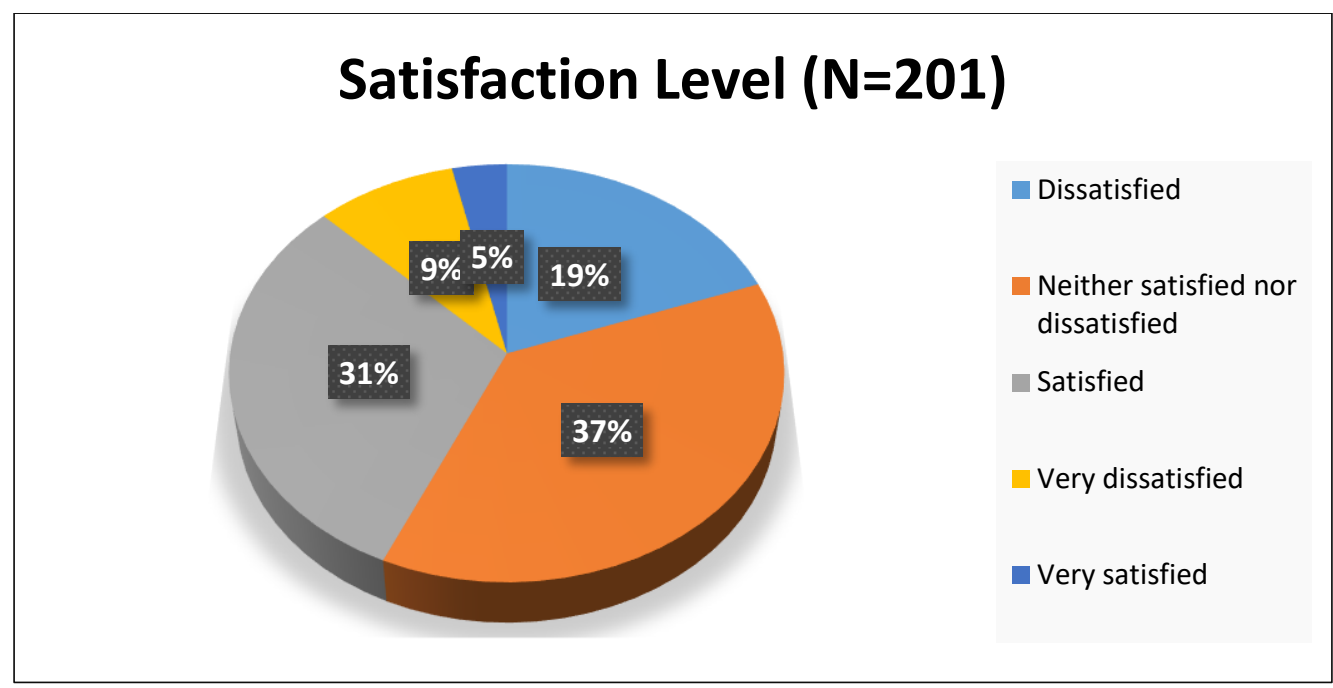

Figure 3. Satisfaction level towards online classes and exams

\section{Necessity of ICT in Medical Education}

Figure-4 represents that majority of the medical undergraduates $(42.3 \%)$ were agree for a primary training on ICT knowledge at the medical course curriculum. $24.4 \%$ of undergraduates neither agreed nor disagreed, $14.9 \%$ were strongly agree, $13.4 \%$ were disagree and $5.0 \%$ strongly disagreed top referred any ICT related education in their course.

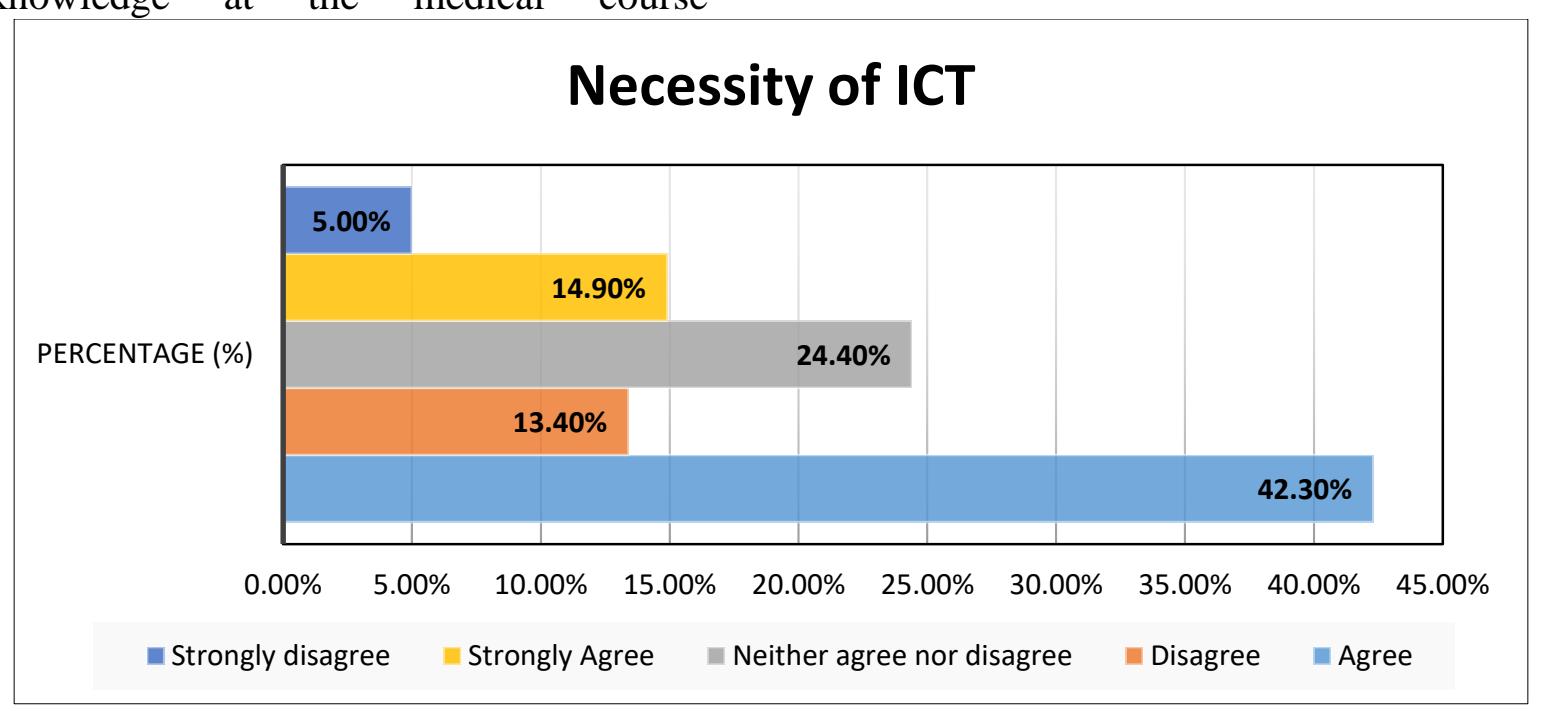

\section{Discussion:}

Figure 4. Necessity of ICT in Medical Education

Nowadays, the ICT is altering the scenery of the globe and guiding us towards a complicated scientific environment. The up-and-coming role of technology has produced a huge collision on health and clinical education. It develops the excellence of heed, improves the smooth operation, ensures the case security as well as reduces the expenses of patient. This was a survey of present state of electronic device used by students and evaluation of ICT knowledge, experience and their opinion. Regarding the use of electronic Bangladesh Journal of Medical Education 2022; 13(1); Islam et al., publisher and licensee Association for Medical Education. This is an Open Access article which permits unrestricted non-commercial use, provided the original work is properly cited. 
devices, our findings work along with the result ofresearch ${ }^{12}$, where highest number of Undergraduates (79.0\%) possessed android phone in addition to health related apps on the android set. In our study students largely (98\%) owned smart phone, while just a marginal (2.0\%) of Undergraduates had no smart phone. The greater part of the respondents, $84.0 \%$, reported their access during online classes with smart phones, $10 \%$ with laptop, $4 \%$ with desktop computer, and $2 \%$ do it with tablet. This finding signifies that elevated intensity of electronic device's handling by students will reasonably be anticipated to make use of digital resources and contribute in academic punitions.

In our study, $76.0 \%$ student favored Whats app and Facebook group for sharing the academic documents with fellow students. Google drive and mail sharing are used by $23.0 \%$ while only $.5 \%$ used Microsoft OneNote sharing platform during COVID19 pandemic.

The study identified the use of medical apps and found $68.6 \%$ of students have medicalrelated apps, only $31.4 \%$ don't use medical apps. So, the growth of medical apps in Bangladesh perspective, related to syndrome diagnosis, medicine orientation, and ailment strategy should be discovered in potential study. Desari et al revealed $60 \%$ adopting health applications for experimental reasons and $47 \%$ for studious behaviors. Our study explored that the two- thirds of respondents have medical apps in their smart phone, with Medscape being the most widely utilized app ${ }^{13}$.

Now-a-days, community based networking has many constructive impacts on teaching and learning including rapid contact, welltimed notifications, entertaining lively, distance learning, developing talent, building successful line of business ${ }^{14}$. The study identified that students used a combination of social media platform with fellow students for academic purpose. Where the majority participants preferred whatsapp group, second highest group favored the messenger group, a good number of students preferred messenger and whatsapp group both, and the small number of students favored and viver and telegram as the media of communication and exchanging with associate fellows.

The study investigated the students learning equipment or media that was used by them to perform the assignment or exam during pandemic situation. The majority of the participants stated Zoom app was the main media device to execute the task, second highest group exposed Google meet, others used Google quizzes form, messenger and whatsapp, email etc. Our result do collaborate with Minahas et al. study where the results shows that Zoom Video Conferencing App was remained the top for the online classes. Students were satisfied about the overall class management and General interface of this application and

Bangladesh Journal of Medical Education 2022; 13(1); Islam et al., publisher and licensee Association for Medical Education. This is an Open Access article which permits unrestricted non-commercial use, provided the original work is properly cited. 
appreciated screen sharing, lecture recording features of the application ${ }^{15}$.

The study examined the students' difficulties in learning efficiently in a Webbased or distance online class. We found the most common problems the medical fellows are presently countering with online classes along with definite instructions on how to deal with them. The majority of the students, $40.8 \%$, encountered bandwidth trouble during online class, $30.3 \%$ found no problem, $8.9 \%$ found lack of IT knowledge, $6.5 \%$ found the problem of disconnecting in the midway, $3.5 \%$ found less qualitative presentation, $3.0 \%$ interrupted in screen sharing, $3.0 \%$ found noisy environment, $2.0 \%$ respondents found sound breaking problem another $2.0 \%$ respondents stated that their apps doesn't run properly in the period of class time

The satisfaction level of the students towards online classes indicates more development needs to achieve to meet the required future professional competency and accomplish the alternative class system. In the present study, majority participants mentioned that they are neither satisfied nor dissatisfied. $30.8 \%$ respondents were satisfied while $19.4 \%$ were dissatisfied and $9.0 \%$ were very dissatisfied and $3.5 \%$ were very satisfied. . The study tried to investigate the necessary of ICT training or learning for medical students in their early stage. Most of the students expressed that preliminary ICT training schedule can be included with the MBBS course. The majority of the respondents, $42.3 \%$, agreed for a primary ICT training in the course curriculum. $24.4 \%$ of under Undergraduates neither agreed nor disagreed, $14.9 \%$ were strongly agree, $13.4 \%$ were disagree and $5.0 \%$ strongly disagreed to have any IT related education in their course. The opening of proper computer literacy in the $1^{\text {st }}$ year MBBS program will make sure the proficiency for proper use of sophisticated overhauls successfully in learning atmosphere $^{16}$. These skills contain the aptitude to look for records to get existing perform strategy, technical knowledge, joining online meetings, and media instruction courses.

The education and learning environments in medical and health institutions are mainly theoretical and most probably arbitrated via a power point arrangement. Social networking is possibly applicable for incorporating the instructive actions. Teachers and students both should incorporate ICT in training and learning actions such as using visualization, creating content videos, developing apps, sending outcomes through digital media, and making the surroundings to facilitate fellow- interceded attitudes to root education, resources, and the path to look forwarded.

Bangladesh Journal of Medical Education 2022; 13(1); Islam et al., publisher and licensee Association for Medical Education. This is an Open Access article which permits unrestricted non-commercial use, provided the original work is properly cited. 
The research tends to some significance of several substitute issues that can be connected to ICT awareness; though it was completely a financial restraint or lack of attention that prohibited digital tools possession and education. Reason known all through the present study may be considered in order to pick up the ICT practice among students of Bangladesh as well as developing and under developed nations with comparable students and conditions.

\section{Conclusion:}

The Covid-19, a worldwide epidemic melodramatically changed the teaching and learning atmosphere all over the world. The students and teachers faced different types of difficulties and gained new experience in their study period. However, the difficulties and barriers should be identified and settled down. Most of the teachers and students with no trustworthy entrance and bandwidth problem resist contributing in remoteness education. The mainstream part of the medical Undergraduates demanded the need of ICT training in the health sector, though the almost Undergraduates holds electronic tools, like smart phone, laptop, desktop, tab etc and have internet access and IT knowledge concerning their academics. Therefore, commencing ICT education at the beginning phase of the MBBS course and reshaping the syllabus to persuade the procedures of ICT is vital to enhance abilities of undergraduates in incorporated education and learning technique.

\section{Reference:}

1. Bauk SI. Assessing Students' Perception of E-Learning in Blended Environment: An Experimental Study. Procedia - Soc Behav Sci. 2015 Jun;191:323-9.

2. Rahaman MdM, Akter N. ICT Used In Education Sector Considering Primary and Secondary Level Schools in Rural Areas: A Study of Sylhet Division in Bangladesh. IOSR J Bus Manag. 2017 Apr;19(04):01-6.

3. Inamdar SC, Rotti SB. Computer use among medical students in an institution in southern India. Natl Med J INDIA. 2004;17(1):4.

4. Platt MW, Obenshain S, Friedman M. Integration of computers into the medical school curriculum: An example from a microbiology course. Med Teach. 1994 Jan;16(1):9-15.

5. Woltering V, Herrler A, Spitzer K, Spreckelsen C. Blended learning positively affects students' satisfaction and the role of the tutor in the problembased learning process: results of a mixed-method evaluation. Adv Health Sci Educ. 2009 Dec;14(5):725-38.

6. Prensky M. Digital Natives, Digital Immigrants Part 1. Horiz. 2001 Sep;9(5):1-6.

7. Serin O. The Effects of the ComputerBased Instruction on the Achievement and Problem Solving Skills of the

Bangladesh Journal of Medical Education 2022; 13(1); Islam et al., publisher and licensee Association for Medical Education. This is an Open Access article which permits unrestricted non-commercial use, provided the original work is properly cited. 
Science and Technology Students. Turk

Online J Educ Technol. 2021;10(1):184201.

8. Trelease RB. Diffusion of innovations: Smartphones and wireless anatomy learning resources. Anat Sci Educ. 2008 Nov;1(6):233-9.

9. McAlearney AS. Organizational and Physician Perspectives about Facilitating Handheld Computer Use in Clinical Practice: Results of a Cross-Site Qualitative Study. J Am Med Inform Assoc. 2005 May 19;12(5):568-75.

10. Prgomet M, Georgiou A, Westbrook JI. The Impact of Mobile Handheld Technology on Hospital Physicians' Work Practices and Patient Care: A Systematic Review. J Am Med Inform Assoc. 2009 Nov 1;16(6):792-801.

11. Shaw M, Adam CJ, Izatt MT, Licina P, Askin GN. Use of the iPhone for Cobb angle measurement in scoliosis. Eur Spine J. 2012 Jun;21(6):1062-8.

12.Payne KFB, Wharrad $\mathrm{H}$, Watts $\mathrm{K}$. Smartphone and medical related App use among medical students and junior doctors in the United Kingdom (UK): a regional survey. BMC Med Inform Decis Mak. 2012 Dec;12(1):121.
13.Dasari KB, White SM, Pateman J. Survey of iPhone usage among anaesthetists in England: Correspondence. Anaesthesia. 2011 Jul;66(7):630-1.

14. Seosajjad. Positive and Negative Impact of Social Media on Education [Internet]. 2020 [cited 2021 Oct 7]. Available from: https://tis.edu.in/blog/positive-andnegative-impact-of-social-media-oneducation/

15. Minhas DS, Hussain T, Ghani A, Sajid K. EXPLORING STUDENTS ONLINE LEARNING: A STUDY OF ZOOM APPLICATION. 2021;9.

16. Gibson KE, Silverberg M. A two-year experience teaching computer literacy to first-year medical students using skillbased cohorts. Gibson K E Silverberg M 2000 Two-Year Exp Teach Comput Lit First-Year MedicalBulletin Med Libr Assoc. 2000;88(2):157-67.

Bangladesh Journal of Medical Education 2022; 13(1); Islam et al., publisher and licensee Association for Medical Education. This is an Open Access article which permits unrestricted non-commercial use, provided the original work is properly cited. 